\title{
Student Feedback On The Effectiveness Of Using A WebQuest For An Integrative Skills Course In A Korean University
}

Chris Kobylinski, Hanguk University of Foreign Studies, South Korea

\begin{abstract}
This paper focuses on the students' feedback after their participation in a WebQuest research project and aims to determine if the format of a WebQuest enhances student interest and engagement with a text compared to a traditional reading. It was hypothesized that students would respond favorably to this format, and that the increased engagement would lead to greater motivation; however, after analyzing student feedback, it was determined that the format alone wasn't successful in promoting student interest and some modifications would be necessary to increase student engagement and motivation.
\end{abstract}

Keywords: WebQuest Activity; EFL Writing Activity; Student Motivation; EFL Reading

\section{RESEARCH PROBLEM AND BACKGROUND}

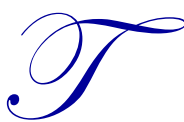

his study began out of the desire to find a more effective and motivating way to incorporate writing into the curriculum of a fours skills (reading, writing, listening, and speaking) English language course for first year students at a Korean university. The mandated text book contains numerous activities that focus on listening, speaking, and reading, but there are very few writing activities. In an effort to find an effective and practical writing component for the class, the author agreed to be a part of a WebQuest research project that was designed to compare the effectiveness of not only a WebQuest, but also the type of discussion the students would participate in after the WebQuest.

According to the creator of the WebQuest, Bernie Dodge (1995), a WebQuest is "an inquiry-orientated lesson format in which most of or all the information that learners interact with comes from resources on the internet." WebQuests also contain the following sections: Introduction, Task, Process, Resources, Evaluation, and Conclusion (Dodge, 2007). Korea is a very high-tech country that uses the internet for a variety of purposes and it was assumed that students living in this environment would be very receptive to an internet-based learning task.

The focus of this study was to evaluate the perceived benefits of a WebQuest format in regards to improving student engagement and motivation, while allowing the students to experience a WebQuest and receive feedback on their writing.

\section{RESEARCH QUESTION}

Does the format of the WebQuest promote student interest and engagement with a reading text, increase motivation, and stimulate writing compared to a traditional reading?

\section{LITERATURE REVIEW}

Initial research on WebQuests centered on the work of Bernie Dodge, the creator of WebQuest, and Tom March, his co-collaborator. March (2003) succinctly declared: 
A Webquest is a scaffolded learning structure that uses links to essential resources on the World Wide Web and an authentic task to motivate students' investigation of a central, open-ended question, development of individual expertise and participation in a final group process that attempts to transform newly acquired information into a more sophisticated understanding. (p. 2)

In simpler terms, Dudeney (2003) summarized the essence of a WebQuest by stating "we might consider WebQuests to be mini-projects in which a large percentage of the input and material is supplied by the Internet." For the most part, the traditional WebQuest is a webpage that contains an introduction, a task, the resources to complete the task or links to these resources, and a final assignment based on information obtained from the task. Given this definition of a WebQuest, what would need to be considered in evaluating it as an effective classroom tool?

First, would be the issue of motivation. In regards to motivation and second language acquisition (hereafter L2), Lourdes Ortega (2009) says, "Motivation is usually understood to refer to the desire to initiate L2 learning and the effort employed to sustain it" (p. 168). With this in mind, the key to examining the link between a WebQuest and motivation would be to see if the format of the WebQuest creates a desire to engage the WebQuest in a way that is different from how one would engage a traditional reading. Halat (2008) points out that WebQuests can increase motivation in this way. Halat says WebQuests can be an "alternative teaching technique that enhances students' motivation" and "allows students to use the Internet as an important tool." Dudeney (2003) expands upon this and says that WebQuests "are both motivating and authentic tasks" that "can be a greater motivator than outdated course books and other such teaching materials."

Besides motivation, previous research also shows that WebQuests promote critical thinking skills. Ikpeze (2007) highlighted this by saying "WebQuests allow students to think critically about an issue and use many skills to develop and defend an opinion." Chatel (2002) also illustrates how WebQuests can encourage and strengthen critical thinking skills. "The question posed to the students can not be answered by simply collecting and spitting back information. Students transform information into something else: a cluster that maps out the main issues, a comparison, a hypothesis, a solution."

Research suggests that WebQuests can increase student motivation and critical thinking skills, but can they be used effectively for writing in an English as a Foreign Language (hereafter EFL) classroom? Research done by Chou suggests that a WebQuest can be used to improve writing in an EFL classroom. The author cites Krashen's (1985) claim that "the best way to learn to write is to obtain rich and comprehensive reading input" and claims that students who participate in the WebQuest "outperformed their counterparts in the traditional writing instruction probably because they spent a substantial amount of time skimming, scanning and decoding relative Web materials for the purpose of communicating their ideas in their writing" (Chou, 2007). It should be noted that this researcher modified a traditional WebQuest with a complimentary system called "WebQuest Writing Instruction" that was "designed to provide input, elicit interaction and encourage output" (Chou, 2007). This is an example of how traditional WebQuests can be modified to better suit the needs of EFL students. Given the overall body of WebQuest research, it was assumed that the WebQuest would produce positive results, be well received by the students, and would increase motivation within the students.

\section{SUBJECTS}

The subjects of this study were Korean university students from four Practical English classes, standard credit-bearing classes for first year students. Each class size ranged from 15 to 22 students. The level of the students ranged from fluent to lower intermediate. Some students had studied and/or lived abroad for extended periods of time and some students had little or no confidence in their English language ability; many fell in the category of upper intermediate and had a good grasp of English and of academic language in their native language. The ages of the students ranged from 18 to 26 . The students of the classes may not have been reflective of the average Korean university, but they were for the most part a good cross section of the students taking Practical English at the researcher's university. For the WebQuest portion of the research each class was divided into three groups of five randomly and each group was given a different treatment. 


\section{APPARATUS OF INSTRUMENTATION}

The research would be divided into three phases: the pre-test, the WebQuest, and the questionnaire. The pretest, involved all students being given articles about two famous artists on paper handouts. Students were then given a set amount of time to read the articles and then write a compare and contrast essay.

The next phase, the WebQuest phase, started a week later and required that students be divided into three groups: the first group would be given a traditional WebQuest and a set amount of time to read the information on the designated WebQuest page and write a compare and contrast essay, a second group would be given a WebQuest, a set amount of time to read the WebQuest and then a set amount of time to discuss the material in an Instructional Conversation discussion via Skype before writing their essays individually; and the final group would be given a set amount of time to read the WebQuest and then a set amount of time to discuss the material in a more traditional ask and answer discussion-style via Skype before writing their essays individually. The compare and contrast essays from the pretests and the WebQuests would be assessed based on a rubric and the data would be analyzed to see which method led to the best results.

The final part of this research conducted by the author would be a qualitative and quantitative questionnaire which would aim to get student feedback about their WebQuest experience. The goal of the questionnaire was to see if students saw any perceived value for the WebQuest, and to determine if WebQuests have the potential for future use in integrated skills courses, specifically for writing assignments.

\section{PROCEDURE}

The research began with a pretest that was administered to each class. All students were given the same pretest, to be completed individually, and the students in each class took the pretest at the same time. The pretest consisted of four printed handouts about two different artists, an instruction sheet, and blank pages for writing. The students were instructed to read the handouts for 50 minutes and then were given forty minutes to write a compare and contrast essay. The essays were then evaluated based on a rubric.

Over the next two weeks, the WebQuest portion of the research took place. During the first week, five students were randomly selected to participate in an experimental WebQuest group. This group would read the WebQuest for 20 minutes and then engage in a discussion via Skype with the experimental teacher for 30 minutes. The experimental teacher used the Instructional Conversation technique during this discussion. After the Skype discussion, the students were given 40 minutes to write a compare and contrast essay with pen and paper and they had access to the WebQuest and the Skype conversations during the writing process. Simultaneously, another randomly selected group of five, acting as the control group, was given a traditional WebQuest proctored by the control teacher. This group read the WebQuest by themselves for 50 minutes and then had 40 minutes to write a compare and contrast essay with pen and paper and they had access to the WebQuest during the writing process. The remaining students stayed in the classroom and participated in a normal class.

The following week, five of the students who had stayed in the classroom the previous week were sent to a computer lab and were given a WebQuest by the experimental teacher. The students had 20 minutes to read the WebQuest and then engaged in a 30 minute Skype discussion with the experimental teacher who used a more traditional ask, answer, and evaluate method to lead the discussion. The students then had 40 minutes to write a compare and contrast essay using pen and paper and they had access to the WebQuest and the Skype conversations during the writing process. The other students who weren't chosen for data collection were given a traditional WebQuest with the control teacher, and these students were given the same treatment as the other students for ethical purposes, but their essays weren't used in the data collection. The ten students who had previously participated in the WebQuest the first week participated in a normal class as the other students had done the week before. All essays from the WebQuests were collected and graded using the same rubric as the pretests.

After completing the WebQuest phase, students were given a brief in-class survey to get their reaction to the WebQuest, the pre-test, and the different types of post-WebQuest discussions they were involved in. In this paper the data collected about student opinions on the WebQuest will be discussed; the other data on student performance may be used in future research. 


\section{DATA COLLECTION}

The questionnaire was administered to all the students in the author's classes who had participated in the research, but not all the questionnaires were used. Questionnaires that were grossly incomplete or completely blank weren't evaluated. In all, 66 questionnaires were analyzed for the data. The survey itself consisted of 22 questions; most questions used a 5-point Likert scale, while others offered choices. Many questions also included a second question designed to illicit a qualitative response from the students.

\section{DATA ANALYSIS AND FINDINGS}

70 students received the questionnaire and 66 completed them in a satisfactory manner. Informed consent was given for the survey in addition to the original informed consent for the WebQuest research. The survey was given in English, but a translated version was also provided in the students' L1 (first language), to ensure that all students understood what was being asked. After the data was analyzed, the initial hypothesis was proven to be wrong; there wasn't much perceived value to the WebQuest and there was very little enjoyment or additional motivation because of the form of the WebQuest.

Overall, students' opinion of the WebQuest format and its effectiveness in assisting comprehension and academic skills development was quite low. The two highest rates of satisfaction were related to the topic choice and to the purpose of the assignment and the lowest measures of student opinion were directly related to questions about the format of the WebQuest. See the table below for a summary of the student opinion about the WebQuest.

Table 1: Result for Selected Survey Questions

\begin{tabular}{|l|c|}
\hline What was your overall opinion of the WebQuest in terms of learning? 1 = learned nothing, 5 = learned a lot & 2.47 \\
\hline I learned/developed academic skills during the WebQuest: $1=\mathrm{SD}, 5=\mathrm{SA}$ & 2.21 \\
\hline What was your opinion of the subject matter? 1 = not relevant, $5=$ very relevant & 3.44 \\
\hline I felt the WebQuest had a clear purpose: $1=\mathrm{SD}, 5=\mathrm{SA}$ & 3.12 \\
\hline Did you enjoy the WebQuest? 1 = no enjoyment, $5=$ extremely enjoyable & 2.04 \\
\hline Rate the WebQuest: 1 = Horrible, $5=$ excellent & 2.15 \\
\hline The format of the WebQuest engaged me in the task: $1=\mathrm{SD}, 5=\mathrm{SA}$ & 2.24 \\
\hline
\end{tabular}

Another thing noted from the data was that there was no perceived benefit from using a WebQuest compared to a traditional handout. Out of 66 students, only 13 preferred reading the WebQuest, 24 showed no preference and 29 preferred reading off the paper. According to the qualitative data that accompanied this question, many students said they preferred being able to take notes on the paper and felt that had they been allowed to use their smart phones with a paper handout, that they could find more information than by just using the WebQuest. Some student comments that reflect this sentiment are: "The WebQuest was just like Wikipedia," "I wanted to see more pictures of the art," "The WebQuest looked very old and simple style," "The WebQuest is so forcing and boring" and "I usually underline when I read text, so I prefer paper work."

On the question that asked about if there was any benefit of doing a WebQuest to a traditional reading, only 24 out of 66 said yes and the most common reason was because the embedded hotlinks made it easier to find some information. One student noted, "In the WebQuest the information about the artists was very specific and the links made things easy to understand." However, many students stated that the embedded hotlinks of the WebQuest were very similar to what is found on most wiki sites.

\section{LIMITATIONS AND SUGGESTIONS FOR FURTHER RESEARCH}

There are many limitations to this study in terms of accurately gauging student opinion about using the WebQuest model. First, the students were told to evaluate the WebQuest just as class activity and not on the basis of the methodology of the WebQuest research project, but they may not have made a distinction between the method and the content. The format of the overall research project meant that students may have spent up to 100 minutes reading materials in class and 80 minutes of class writing essays. This may not have been viewed as productive class management, as these types of activities are usually done outside of the classroom. 
Also, although the student's opinion of the relevance of the subject matter scored higher than the other questions of the survey, the subject matter itself may not have been interesting to the students and may have tainted their evaluations.

Another limitation was that the WebQuests were conducted by teachers that the students weren't familiar with and may or may not have enjoyed working with. The students spent at least 90 minutes in small groups with a new teacher who had been brought in to oversee the control group and lead the discussions of the other two WebQuest groups and the students may or may not have felt as comfortable with them.

Additionally, the format of the WebQuest could be seen as very restrictive in this modern environment. When WebQuests were developed in the mid-90s, the WebQuest itself could provide access to information that would be very difficult for students to find on their own, however, with access to smart phones, the use of embedded links within a WebQuest may be seen as a very restrictive and controlling factor, because it leads the reader to the information that the administrator wants the reader to see and may not necessarily be the way the reader prefers to find his or her information. For example, with this particular WebQuest, a few students complained that they couldn't use a Google image search to see a greater variety of paintings.

Finally, the questionnaire focused solely on the students' opinions and not on the quality of their output. At the time of this writing, the data from the WebQuest portion wasn't available for public dispersal, and may be used in future research on student achievement.

\section{CONCLUSION}

The overwhelmingly negative student response to the WebQuest shows that students believed that the actual format of the WebQuest didn't improve their motivation and didn't give them better access to materials. Evidence of this was seen in the student responses. For example, one of the more revealing questions on student attitude asked "there are many free WebQuests available online, will you ever try one?" Out of the 66 students, only one responded definitely, 6 said probably, 16 said maybe, 21 said probably not, and 22 said never. This was quite surprising, because it is common for students to ask how they can improve their English outside of class, and they were given links to various free WebQuests. Interestingly, the one student who responded definitely said that he was headed to the army and would have time to try them out. When asked if a WebQuest should be included in the next year's curriculum, only 18 said yes and 48 said no. The last question asked the students to rate the WebQuest as an activity, as opposed to a research project and the overall rating was 2.24 out of 5 . To put this in perspective, in a later survey asking to rate various activities done in class, the same students gave the next lowest ranked activity a score of 3.86 .

When the student data is looked at holistically, it can be concluded that the students would better be served by having pre-reading and post-reading discussions and activities and that these activities don't necessarily need to be in a WebQuest format. The one advantage of the WebQuest was that it ensured that students were getting their information in the target language and that the information was coming from a reliable source. However, this isn't always practical to expect from students in an EFL environment and it may be better to focus on teaching students how and where to search for information and how to skim and scan articles in English, as these skills could be used later on, while a WebQuest would just be a onetime experience.

The author does see where a WebQuest could be valuable for younger students or for students in an ESL setting learning how to access information in the target language, but did not see the value of the WebQuest in this traditional format for the classes that participated in the research. Additionally, if a WebQuest was modified to include something similar to what Chou (2007) did with the "WebQuest Writing Instruction," the WebQuest could be more effective. Some examples of modifications may include using Skype or messaging services for collaboration and organization, using smart phones for in class WebQuests, or using a service such as Google Drive for peer editing.

Overall, the author doesn't want to discredit the overall idea of a WebQuest, but maintains that the actual computer format for a traditional WebQuest doesn't improve student engagement with the text and may not be essential to achieve similar output from the students. 


\section{ACKNOWLEDGEMENT}

This work was supported by Hankuk University of Foreign Studies Research Fund of 2013.

\section{AUTHOR INFORMATION}

Chris Kobylinski has taught Practical English at Hanguk University of Foreign Studies in Seoul, South Korea for the past six years. Practical English is a 4-skills course designed to prepare First Year University students from NonEnglish Majors for future university classes taught in English. Preparing students to study in English at a university level in South Korea provides a unique challenge and allows him to search for and use various methods and activities in class. Chris Kobylinski obtained his B.A. in English from the College of the Holy Cross and his M.Ed (TESOL) from Framingham State University. E-mail: chriskoby@gmail.com

\section{REFERENCES}

1. Chatel, R. G., \& Nodell, J. (2002). WebQuests: Teachers and students as global literacy explorers. Connecticut Reading Association.

2. Chou, T.-W. I. (2007). The Effects of the WebQuest writing instruction program on EFL learners' wrtiting performance, writing apprehension, and perception. TESL-EJ, 11(3).

3. Dodge, B. (1995). Some thoughts about WebQuests. Retrieved from http://edweb.sdsu.edu/courses/edtec596/about_webquests.htnl

4. Dodge, B. (2007). WebQuest.org. SDSU.

5. Dudeney, G. (2003). The quest for practical web usage. TESL-EJ, 6(4).

6. Halat, E. (2008). A good teaching technique: WebQuests. Heldref Publications.

7. Ikpeze, C. H.; Boyd, F. B. (2007). Web-based inquiry learning: Facilitating thoughtful literacy with WebQuests. International Reading Association.

8. March, T. (2009). What WebQuests are (really). zj [2002-2005], bron.

9. Ortega, L. (2009). Understanding second language acquisition. London: Hodder Education. 